\title{
Penalaran analogi siswa tipe campers dalam menyelesaikan soal persamaan logaritma
}

\author{
Nurul Chamisah, Sukoriyanto* \\ Universitas Negeri Malang, Jl. Semarang No. 5 Malang, Jawa Timur, Indonesia \\ *Penulis korespondensi, Surel: sukoriyanto.fmipa@um.ac.id
}

Paper received: 01-09-2021; revised: 15-09-2021; accepted: 30-08-2021

\begin{abstract}
The purpose of this descriptive qualitative research is to describe the analogical reasoning from 6 students with campers type in the X-grade of IPA 1 SMA Nasional Malang. Analogical reasoning id described based on encoding, inferring, mapping and applying stage. The data collected in this research are the result of the questionnaire. The research shows that analogical reasoning of the campers students are correct in the stage of encoding, inferring and mapping. It also found that the campers students made mistake on the stage of applying in doing the target problem caused by less accuracy, having wrong concept of logarithm, and the influence of perception mapping in the source problem which is directly associated to the target problem without firstly analyzing the target problem.
\end{abstract}

Keywords: Analogical Reasoning; Campers students; Logarithm equation.

\begin{abstract}
Abstrak
Tujuan penelitian deskriptif kualitatif ini adalah mendeskripsikan penalaran analogi dari 6 siswa tipe campers pada kelas X IPA 1 SMA Nasional Malang. Penalaran analogi dideskripsikan berdasarkan tahapan pengkodean (encoding), penyimpulan (inferring), pemetaan (mapping), dan penerapan (applying). Data yang dikumpulkan dalam penelitian ini adalah jawaban siswa atas soal masalah analogi serta hasil wawancara. Hasil penelitian ini menunjukkan bahwa penalaran analogi subjek tipe campers pada tahap pengkodean, penyimpulan, dan pemetaan mampu melakukan dengan benar. Sedangkan pada tahap penerapan terdapat kesalahan dalam menyelesaikan masalah target yang diakibatkan karena kurang teliti, salah konsep logaritma dan pengaruh pemetaan persepsi yang ada pada masalah sumber yang langsung disesuaikan ke dalam situasi masalah target tanpa analisis pada masalah target terlebih dahulu.
\end{abstract}

Kata kunci: Penalaran Analogi; Siswa Tipe Campers; Persamaan Logaritma

\section{Pendahuluan}

Penalaran merupakan salah satu proses pembelajaran matematika yang dapat membuat siswa berpikir matematis, serta memiliki pengetahuan dan keterampilan dasar matematika, sedemikian sehingga sangatlah penting penalaran dalam proses pembelajaran matematika. Menurut Shadiq (2004), penalaran merupakan suatu proses berpikir untuk menarik kesimpulan berdasarkan beberapa pernyataan yang kebenarannya telah dibuktikan. Penalaran perlu dikembangkan dalam pembelajaran matematika, sesuai dengan tujuan pendidikan nasional Indonesia dalam Permendiknas No 22 tahun 2006 tentang standar isi khususnya pada pembelajaran matematika yaitu agar siswa dapat menggunakan penalaran pada pola, sifat, melakukan manipulasi matematika dalam membuat generalisasi, menyusun bukti, atau menjelaskan gagasan, dan pernyataan matematika. Berdasarkan hal tersebut maka penalaran merupakan kemampuan yang sangat penting dalam belajar matematika khususnya dalam menyelesaikan masalah matematika.

Pentingnya penalaran dalam menyelesaikan masalah matematika tidak sesuai dengan hasil PISA yang diselenggarakan secara internasional oleh OECD, dapat terlihat bahwa 
kemampuan penalaran siswa Indonesia masih rendah. Rendahnya hasil PISA dalam bidang matematika menunjukkan bahwa penalaran siswa di Indonesia dapat dikatakan masih rendah dikarenakan dalam menyelesaikan soal PISA dibutuhkan suatu proses bernalar. Salah satu cara untuk menumbuhkan penalaran siswa dengan pemberian pembelajaran yang menekankan pada analogi matematika merupakan salah satu upaya untuk menumbuhkan penalaran siswa (Kariadinata, 2012).

Menurut English (2012), penalaran analogi terdapat beberapa komponen yang harus dilalui siswa yaitu tahap pengkodean yaitu siswa dapat mengidentifikasi unsur-unsur pada masalah sumber dan masalah target dengan menuliskan dalam bentuk simbol semua fakta yang diketahui dan yang ditanyakan dalam masalah, tahap penyimpulan yaitu siswa dapat mencari unsur-unsur yang diketahui dengan langkah-langkah penyelesaian dan penggunaan konsep yang tepat pada masalah sumber, tahap pemetaan yaitu siswa mampu menemukan hubungan yang sama antara masalah sumber dan masalah target dan memilih metode penyelesaian yang tepat dan tahap penerapan yaitu siswa mampu menyelesaikan masalah target dengan tepat yang mengacu cara penyelesaian atau konsep yang sama dengan masalah sumber

Seseorang dapat menyelesaikan masalah dengan baik apabila didukung oleh kemampuan penyelesaian masalah yang baik pula. Kemampuan yang dimiliki seseorang untuk mengubah dan mengolah suatu permasalahan yang terjadi dalam hidupnya dan menjadikan masalah tersebut menjadi suatu tantangan yang harus diselesaikan dengan sebaik-baiknya dikenal dengan $A Q$, hal tersebut sesuai dengan hasil penelitian oleh Wardiana, dkk. (2014), "selain $I Q$ dan $E Q$ ada faktor lain yang menunjang prestasi belajar yaitu $A Q . " ~ A Q$ didefinisikan sebagai kecerdasan dalam mengatasi masalah yang juga berpengaruh dalam kesuksesan seseorang karena jika $A Q$ siswa tinggi maka siswa mampu untuk megendalikan diri di tengah masalah yang dimilikinya. Stoltz (2000:18-19) menjelaskan secara garis besar $A Q$ terdiri dari tiga tipe yaitu siswa dengan tipe climbers memiliki ciri-ciri selalu siap menghadapi rintangan yang ada, tidak mudah putus asa dan selalu ingin mencapai puncak kesuksesan. Siswa campers memiliki ciri-ciri mudah puas dengan apa yang sudah diperoleh dan tidak mau mengambil resiko terhadap apa yang akan terjadi, dan apabila mengambil resiko pasti dengan penuh perhitungan. Siswa dengan tipe quitters memiliki ciri-ciri mudah menyerah dalam menghadapi masalah yang ada dan cenderung pasif.

Dalam hal masalah analogi dan keterkaitannya terhadap siswa bertipe campers, menimbulkan pertanyaan apakah dalam menyelesaikan masalah analogi siswa tipe campers dapat menggunakan penalaran analogi sehingga mampu mencari keterkaitan sifat dari dua konsep yang sama atau berbeda melalui perbandingan, sehingga siswa dapat menarik kesimpulan dari keterkaitan tersebut dan menyelesaikan masalah analogi dengan benar ataukah hanya sampai pada tahap menerapkan penyelesaian masalah sumber terhadap masalah target karena sifatnya yang mudah puas dan hanya memiliki sejumlah inisiatif, sedikit semangat, tidak menggunakan seluruh kemampuannya, tidak mau mengambil resiko terhadap apa yang akan terjadi dan apabila mengambil resiko dengan penuh perhitungan tersebut?. Oleh karena itu penting dilakukan penelitian tentang penalaran analogi siswa tipe campers dalam menyelesaikan soal persamaan logaritma. Dengan demikian, tujuan penelitian ini adalah untuk mendeskripsikan penalaran analogi siswa tipe campers dalam menyelesaikan soal persamaan logaritma. 


\section{Metode}

Penelitian berjenis deskriptif dengan pendekatan kualitatif ini dilaksanakan di SMA Nasional Malang dengan subjek penelitian siswa tipe campers pada kelas X IPA 1 sebanyak 6 siswa. Data yang akan dikumpulkan dalam penelitian ini yaitu hasil pengerjaan angket $A R P$, hasil pengerjaan masalah analogi dan hasil wawancara subjek penelitian. Pengumpulan data yang dilakukan pada penelitian ini adalah melalui observasi, pengajuan masalah, wawancara dan dokumentasi. Observasi dilakukan pada saat peneliti melaksakan KPL yaitu pemberian soal tentang masalah analogi yang terdiri dari dua soal dengan materi persamaan eksponen dan dua soal dengan materi logaritma sebagai observasi awal dan juga observasi awal dilakukan dengan pemberian angket $A R P$ sehingga menghasilkan tipe campers yang akan menjadi subjek penelitian karena merupakan tipe paling dominan dalam kelas tersebut, setelah itu pada tahap mengajukan masalah, siswa tipe campers diberikan soal masalah analogi dengan materi persamaan logaritma untuk mengetahui penalaran analogi yang digunakan. Masalah analogi yang dijadikan soal penelitian seperti pada Gambar 1 Masalah Sumber dan Gambar 2 Masalah Target di bawah ini.

Gambar 1 Masalah Sumber

\section{MASALAH SUMBER}

Diberikan persamaan kuadarat dinyatakan sebagai

$$
x^{2}-7 x+12=0
$$

Tentukan pembuat nol persamaan kuadrat di atas !
Gambar 2 Masalah Target

\section{MASALAH TARGET}

Diberikan persamaan logaritma dinyatakan sebagai :

$$
\left({ }^{3} \log x\right)^{2}-7 .{ }^{3} \log x+12=0
$$

Tentukan pembuat nol persamaan logaritma di atas !

Pada tahap wawancara, digunakan wawancara terstruktur yaitu melalui pertanyaanpertanyaan yang telah disusun sebelumnya yang dapat mengungkap penalaran analogi siswa dalam menyelesaikan masalah analogi yang diberikan. Wawancara dilakukan terhadap 6 subjek tipe campers yang memiliki sebagian besar jawaban dari seluruh siswa tipe campers.

Teknik analisis data yang digunakan pada penelitian ini adalah konsep Miles dan Hubeman dengan tahap pertama mereduksi data yaitu langkah dalam proses yang meliputi kegiatan menyeleksi, memfokuskan, dan menyederhanakan semua data yang diperoleh mulai dari awal pengumpulan data sampai penyusunan laporan penelitian. Oleh karena itu dari lembar hasil pengerjaan masalah analogi dan hasil rekaman atau transkip wawancara dapat dilakukan reduksi data sehingga peneliti dapat membuat kesimpulan yang akurat dan dapat dipertanggung-jawabkan. Setelah itu dilakukan penyajian data. Penyajian data tersebut dilakukan dalam rangka pengorganisasian informasi hasil reduksi yang disusun secara naratif dan pemberian diagram alur penalaran analogi (Flowchart) sesuai dengan komponen berikut: pengkodean, penyimpulan, pemetaan, dan penerapan. Penarikan kesimpulan bertujuan untuk memberikan penjelasan tentang makna data yang telah disajikan.

\section{Hasil dan Pembahasan}

\subsection{HASIL}

Peneliti melakukan analisis hasil angket $A R P$ dan memetakan setiap siswa ke dalam tipe yang ditinjau dari $A Q$. Dari analisis yang telah didapatkan distribusi tipe siswa X IPA 1 SMA Nasional Malang ditinjau dari $A Q$ dapat dilihat pada Tabel 1 berikut. 
Tabel 1 Distribusi Tipe Siswa X IPA 1 SMA Nasional Malang Ditinjau dari $A Q$

\begin{tabular}{lll}
\hline No & Tipe $\boldsymbol{A Q}$ & Banyak Siswa \\
1 & Quitters & 3 siswa \\
2 & Peralihan Quitters ke Campers & 1 siswa \\
3 & Campers & 18 siswa \\
4 & Peralihan Campers ke Climbers & 2 siswa \\
5 & Climbers & 3 siswa \\
\hline
\end{tabular}

Setelah itu, pemberian soal masalah analogi kepada siswa tipe campers dan menghasilkan 8 siswa campers yang memiliki jawaban dari sebagian besar siswa campers kerjakan tersebut, kemudian dari 8 siswa tipe campers yang menjadi calon subjek dalam penelitian ini. Dengan alasan komunikasi, guru menyarankan 6 siswa bertipe campers yang menurut beliau dapat digunakan sebagai subjek. Berikut deskripsi penalaran analogi 6 siswa tipe campers di bawah ini.

\subsubsection{Deskripsi Penalaran Analogi Siswa Tipe Campers Pertama (SC1)}

Diagram alur penalaran analogi yang terjadi pada subjek SC1 dalam menyelesaikan masalah yang diberikan, ditunjukkan pada Gambar 3 berikut.

Gambar 3 Diagram Alur Penalaran Analogi Pada Subjek SC1

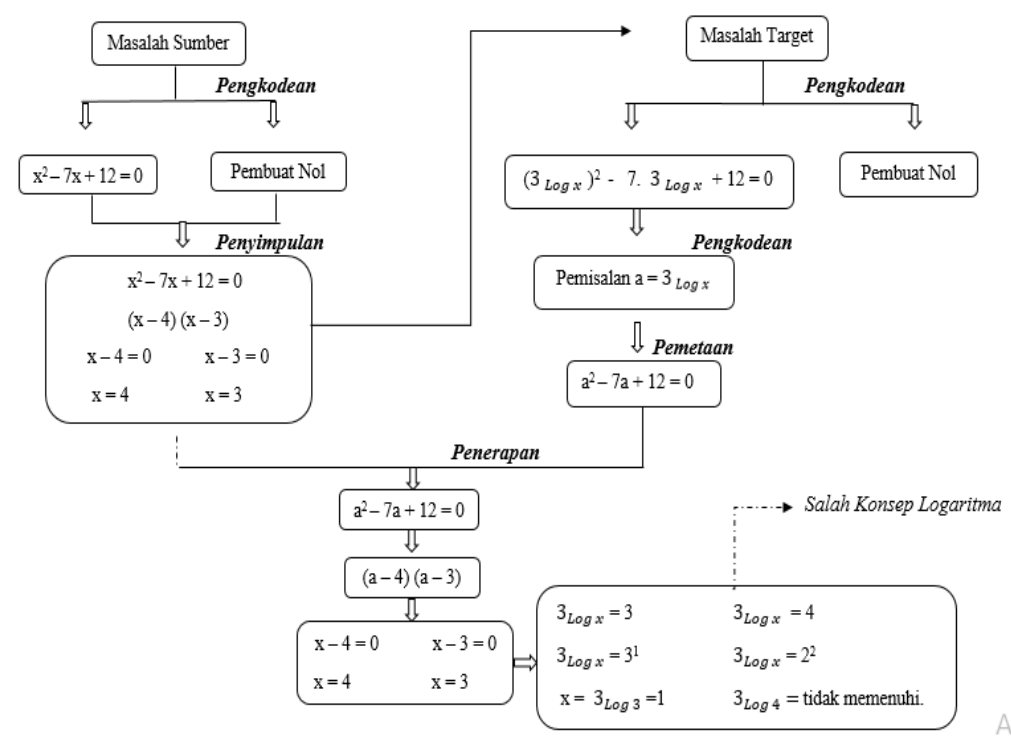

Dari Gambar 3 diagram di atas, dapat diketahui bahwa penalaran analogi SC1 dalam menyelesaikan masalah analogi yaitu mampu melalui tahap pengkodean, penyimpulan dan pemetaan dengan benar, akan tetapi pada tahap penerapan yang dilakukan SC1 tidak benar, hal ini dikarenakan SC1 masih bingung dan merasa salah konsep dalam menggunakan sifat logaritma, sehingga walaupun sudah mengetahui nilai a nya tetapi hasil akhirnya tetap salah. 


\subsubsection{Deskripsi Penalaran Analogi Siswa Tipe Campers Kedua (SC2)}

Diagram alur penalaran analogi yang terjadi pada subjek SC2 dalam menyelesaikan masalah yang diberikan, ditunjukkan pada Gambar 4 berikut.

\section{Gambar 4 Diagram Alur Penalaran Analogi Pada Subjek SC2}

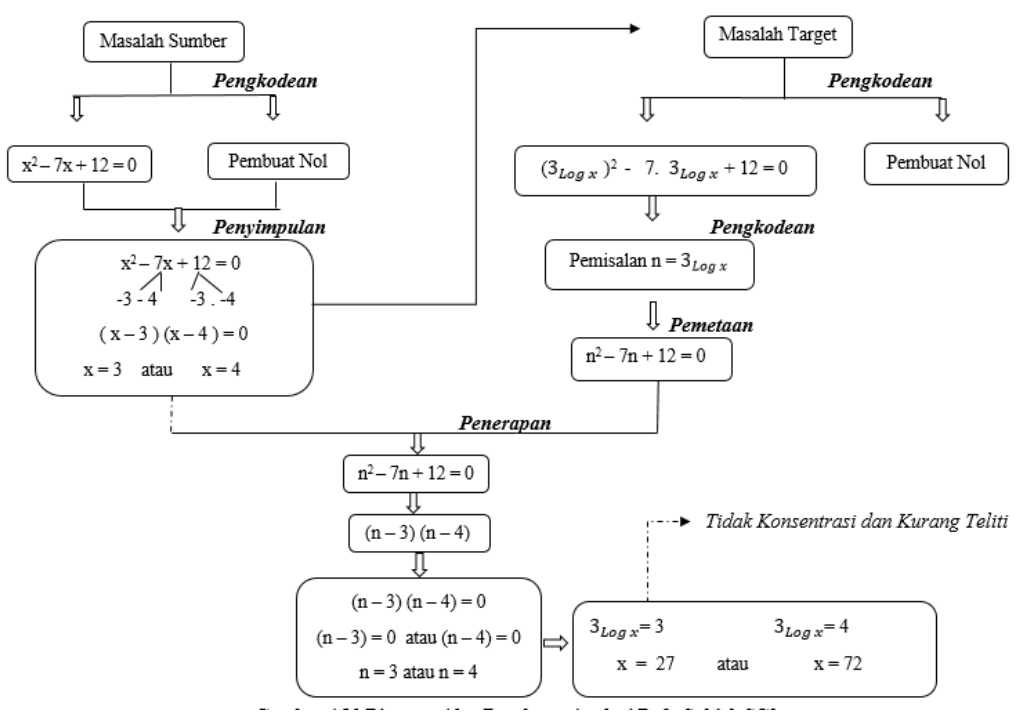

Dari Gambar 4 diagram di atas, dapat diketahui bahwa penalaran analogi SC2 dalam menyelesaikan masalah analogi yaitu mampu melalui tahap pengkodean, penyimpulan dan pemetaan dengan benar, akan tetapi pada tahap penerapan yang dilakukan SC2 tidak benar, hal ini dikarenakan SC2 tidak konsentrasi dan kurang teliti dalam menghitung hasil akhir setelah SC2 menggunakan sifat logaritma. Sehingga walaupun sudah mengetahui cara detailnya seperti apa tetapi hasil akhirnya tetap salah

\subsubsection{Deskripsi Penalaran Analogi Siswa Tipe Campers Ketiga (SC3)}

Diagram alur penalaran analogi yang terjadi pada subjek SC3 dalam menyelesaikan masalah yang diberikan, ditunjukkan pada Gambar 5 berikut.

\section{Gambar 5 Diagram Alur Penalaran Analogi Pada Subjek SC3}

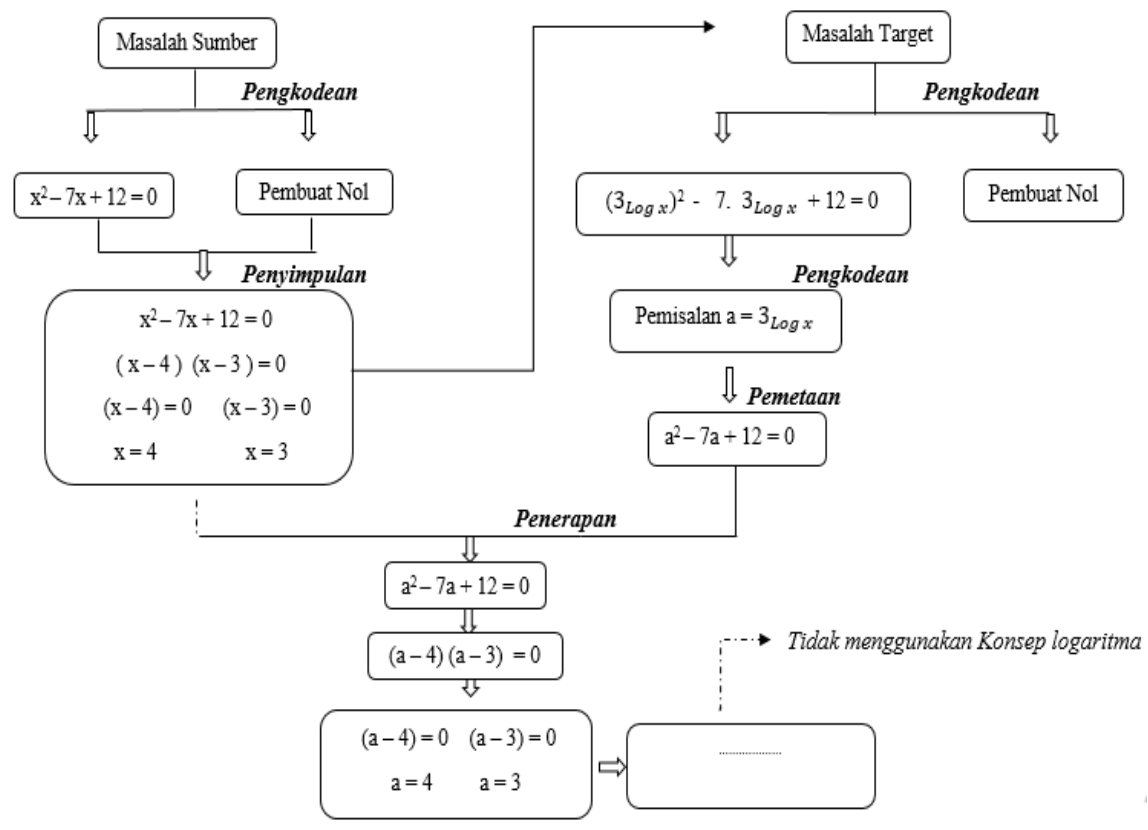


Dari Gambar 5 diagram di atas, dapat diketahui bahwa penalaran analogi SC3 dalam menyelesaikan masalah analogi yaitu mampu melalui tahap pengkodean, penyimpulan dan pemetaan dengan benar, akan tetapi pada tahap penerapan yang dilakukan SC3 tidak benar, hal ini dikarenakan SC3 tidak menggunakan sifat logaritma di mana dia masih belum merubah dari bentuk logaritma ke dalam bentuk eksponen dan hasilnya masih dalam bentuk a bukan variabel $\mathrm{x}$.

\subsubsection{Deskripsi Penalaran Analogi Siswa Tipe Campers Keempat (SC4)}

Diagram alur penalaran analogi yang terjadi pada subjek SC4 dalam menyelesaikan masalah yang diberikan, ditunjukkan pada Gambar 6 berikut.

Gambar 6 Diagram Alur Penalaran Analogi Pada Subjek SC4

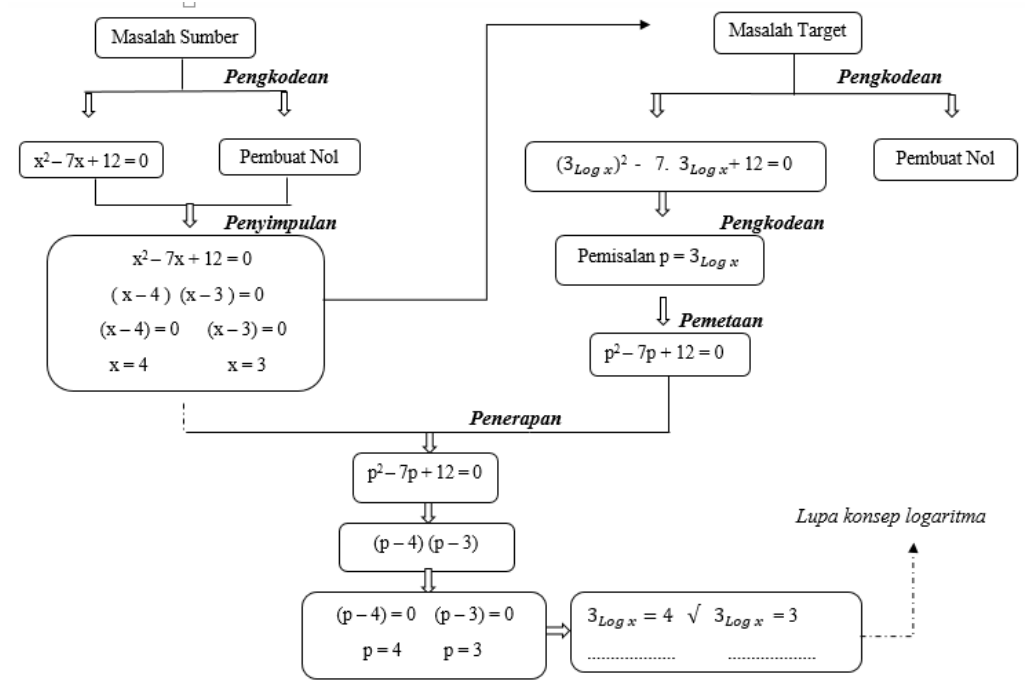

Dari Gambar 6 diagram di atas, dapat diketahui bahwa penalaran analogi SC4 dalam menyelesaikan masalah analogi yaitu mampu melalui tahap pengkodean, penyimpulan dan pemetaan dengan benar, akan tetapi pada tahap penerapan yang dilakukan SC4 tidak benar, hal ini dikarenakan SC4 tidak mampu menggunakan sifat logaritma karena lupa. SC4 hanya mampu merubah pemisalan ke dalam bentuk logaritma, hanya saja dia masih belum merubah dari bentuk logaritma ke dalam bentuk eksponen dan tidak memiliki hasil.

\subsubsection{Deskripsi Penalaran Analogi Siswa Tipe Campers Kelima (SC5)}

Diagram alur penalaran analogi yang terjadi pada subjek SC5 dalam menyelesaikan masalah yang diberikan, ditunjukkan pada Gambar 7 berikut.

Gambar 7 Diagram Alur Penalaran Analogi Pada Subjek SC5

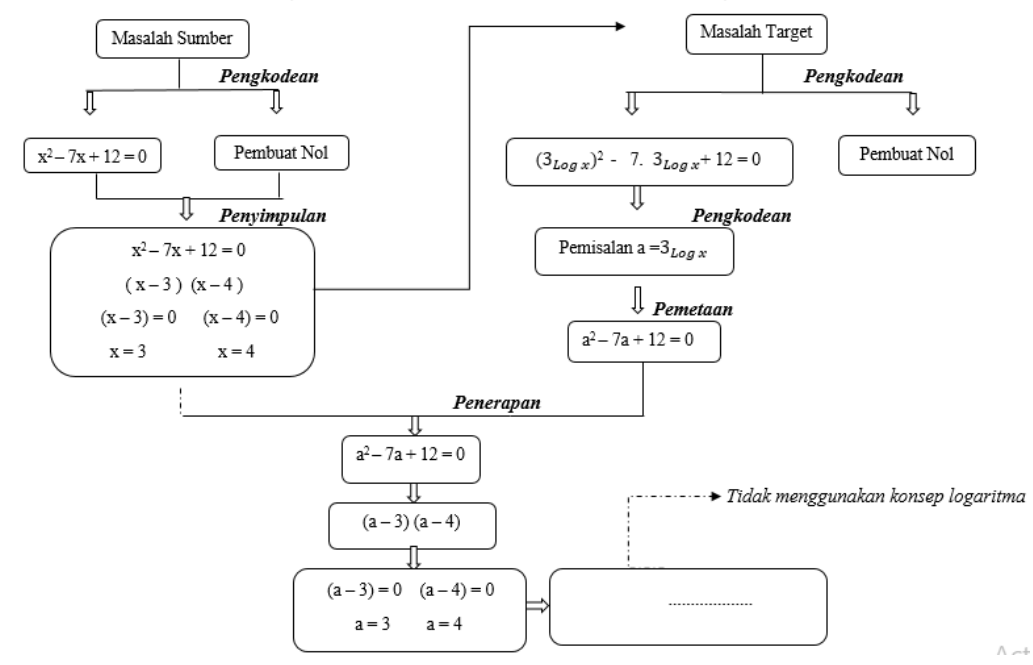


Dari Gambar 7 diagram di atas, dapat diketahui bahwa penalaran analogi SC5 dalam menyelesaikan masalah analogi yaitu mampu melalui tahap pengkodean, penyimpulan dan pemetaan dengan benar, akan tetapi pada tahap penerapan yang dilakukan SC5 tidak benar, hal ini dikarenakan SC5 lupa dengan tahap selanjutnya sehingga hasil yang didapat masih dalam bentuk variabel a, SC5 masih belum menggunakan sifat logaritma.

\subsubsection{Deskripsi Penalaran Analogi Siswa Tipe Campers Keenam (SC6)}

Diagram alur penalaran analogi yang terjadi pada subjek SC6 dalam menyelesaikan masalah yang diberikan, ditunjukkan pada Gambar 8 berikut.

Gambar 8 Diagram Alur Penalaran Analogi Pada Subjek SC6

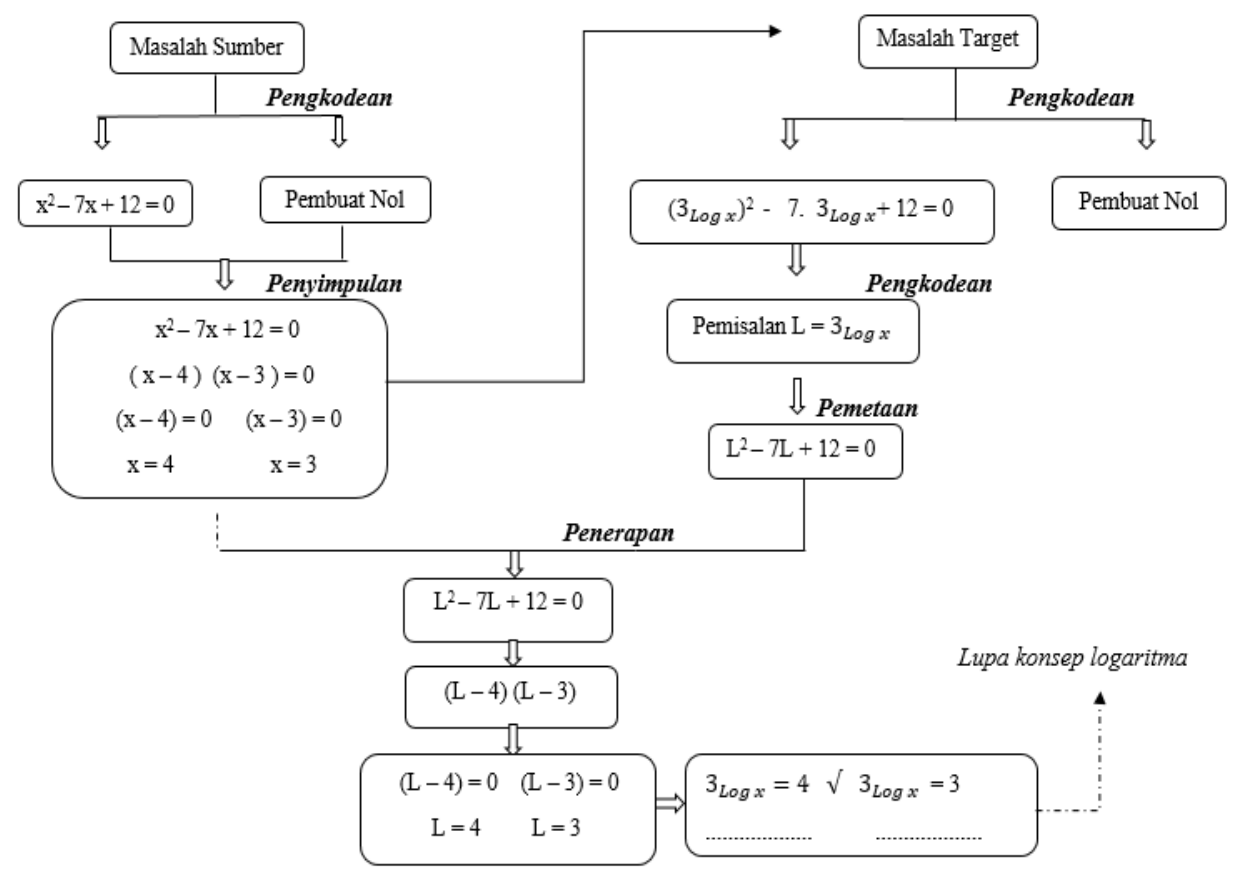

Dari Gambar 8 diagram di atas, dapat diketahui bahwa penalaran analogi SC6 dalam menyelesaikan masalah analogi yaitu mampu melalui tahap pengkodean, penyimpulan dan pemetaan dengan benar, akan tetapi pada tahap penerapan yang dilakukan SC6 tidak benar, SC6 hanya bisa mengerjakan sampai pengubahan kembali apa yang dimisalkan sebagai L setelah itu SC6 belum merubah dari bentuk logaritma ke dalam bentuk eksponen dan tidak memiliki hasil. Hal tersebut disebabkan SC6 tidak mampu menggunakan sifat logaritma karena bingung bagaimana cara mengerjakannya. 


\subsection{PEMBAHASAN}

Berikut pembahasan tahapan penalaran analogi pada siswa tipe campers.

\subsubsection{Tahap Pengkodean}

Keenam subjek melakukan tahap pengkodean pada masalah sumber dan masalah target dengan menuliskan apa yang diketahui pada lembar jawaban siswa. Permasalahan pada tahap ini yaitu keterampilan dalam penulisan secara runtut apa yang diketahui dan apa yang ditanyakan, semua subjek dalam penelitian ini hanya menuliskan apa yang diketahui saja sedangkan tidak menuliskan apa yang ditanyakan. Hal tersebut dikarenakan kebiasaan siswa dalam menuliskan jawaban. Didukung oleh Sumardyono (2010) mengatakan kuat diduga kesalahan dalam melakukan penyimbolan terjadi karena kebiasaan yang dilakukan siswa, pengaruh pra konsepsi (sebagian besar didasarkan pada makna bahasa sehari-sehari) dan sumber belajar yang keliru (prakter pengajaran guru dan buku pelajaran).

Keenam subjek menyadari pada masalah target akan menggunakan sifat-sifat logaritma diakhir tahap dalam menyelesaikan soal tersebut. Pada tahap pengkodean ini, keenam subjek memiliki pemisalan variabel yang berbeda. Hal tersebut didukung oleh Solso \& Maclin (dalam Khair, 2018) menyatakan bahwa mempresentasikan segala yang diketahui atau yang ditanyakan secara visual, verbal, simbolis dan lain sebagainya merupakan salah satu faktor yang dapat membantu individu dalam memecahkan masalah. Dari segala dipaparkan di atas, keberhasilan semua subjek dalam melakukan tahap pengkodean diawali dengan pemahaman terhadap masalah sumber dan masalah target, hal tersebut sesuai dengan pendapat English (2012) menyatakan bahwa tahap pengkodean siswa diharuskan sudah mengetahui dan mampu membuat simbol yang digunakan untuk mempresentasikan unsur-unsur pada masalah sumber dan masalah target.

\subsubsection{Tahap Penyimpulan}

Tahap penyimpulan yang dilakukan oleh subjek terkait masalah sumber merupakan hubungan yang didapat dari apa yang diketahui dan ditanyakan, ykni persamaan kuadrat dan pembuat nol. Keenam subjek penelitian telah berhasil menafsirkan hubungan yang diminta oleh soal. Keenam subjek menafsirkan arti pembuat nol. Keenam subjek berhasil menemukan bahwa masalah sumber sudah berbentuk persamaan kuadrat. Setelah melihat karakteristik tersebut keenam subjek menyimpulkan bahwa hubungan komponen-komponen yang ada pada masalah sumber adalah penyelesaian persamaan kuadrat. Keenam subjek penelitian ini menggunakan cara faktorisasi bentuk aljabar atau pemfaktoran.

Tahap penyimpulan yang dilakukan subjek sesuai dengan pendapat English (2012) yang menyatakan bahwa tahap penyimpulan dilakukan untuk menemukan hubungan pada masalah sumber berdasarkan unsur-unsur yang diketahui dengan langkah-langkah penyelesaian dan penggunaan konsep yang tepat.

\subsubsection{Tahap Pemetaan}

Pemetaan yang dilakukan oleh subjek pada masalah sumber dan masalah target adalah melihat kesamaan 2 komponen pada masing-masing masalah. Keenam subjek telah berhasil memetakan komponen yang diketahui dan ditanyakan pada masalah sumber ke komponen yang diketahui dan ditanyakan pada masalah target. Keenam subjek menyadari bahwa apa 
yang diketahui hampir sama, yakni bentuk persamaan kuadrat akan tetapi pada nomor 2 variabel-variabelnya terletak dalam logaritma, dan keenam subjek menyadari bahwa apa yang ditanyakan sama yakni mencari pembuat nol dari persamaan yang diketahui.

Setelah itu untuk masalah target, keenam subjek mengubah persamaan kuadrat logaritma menjadi persamaan kuadrat dengan melakukan pemisalan ${ }^{3} \log \quad x$ dengan variabel lain sesuai dengan apa yang mereka inginkan. Dengan demikian, keenam subjek tersebut dapat melihat dengan jelas letak kesamaan komponen sehingga mudahkan keempat subjek menerapkan metode penyelesaian masalah sumber ke dalam masalah target. Hal tersebut sesuai dengan pendapat menurut English (2012) yang menyatakan bahwa tahap pemetaan dilakukan untuk melihat hubungan apa yang sama antara komponen-komponen pada masalah sumber dengan komponen-komponen pada masalah target.

\subsubsection{Tahap Penerapan}

Tahap penerapan ini subjek mampu menerapkan aturan yang berlaku pada masalah sumber ke masalah target setelah hubungan diantara kedua masalah tersebut diketahui. Hal tersebut sesuai dengan pengertian tahap penerapan yang dikemukakan oleh English (2012) bahwa setelah melihat kesamaan hubungan, kemudian tahap penerapan nya yaitu penyelesaian pada masalah sumber bisa diterapkan pada masalah target dengan terlebih dahulu memodifikasi masalah target.

Subjek-subjek yang telah menggunakan penyelesaian berupa faktorisasi bentuk aljabar masih saja melakukan beberapa kesalahan. Kesalahan pertama berkaitan dengan pemahaman siswa tentang konsep logaritma. Hal tersebut tidak begitu menjadi perhatian khusus oleh kedua subjek ini, terlihat subjek berikut sudah tidak mampu lagi mengerjakan dan terlihat tidak berusaha semaksimal mungkin, mereka berusaha sekedarnya saja. SC2 melakukan kesalahan ketika mengubah interpretasi logaritma ke dalam bentuk eksponen. Hal tersebut terjadi ketika SC2 menghitung hasil akhir dari ${ }^{3} \log x=4$. SC2 menjawab 72 dan jawaban tersebut salah padahal seharusnya dengan menggunakan konsep $b=a^{c}$ hasilnya adalah 81. Menurut hasil wawancara siswa tersebut yakin atas jawaban yang dia berikan sehingga untuk SC2 penerapan tidak sempurna dikarenakan tidak teliti.

Selain SC2, kesalahan yang ditunjukkan SC1 lebih fatal ketika mengubah interpretasi logaritma ke dalam bentuk eksponen. Permasalahan subjek SC1 dan SC2 begitu fatal, karena pentingnya pemahaman suatu konsep yang harus dimiliki oleh siswa akan berpengaruh terhadap konsep lain yang berhubungan untuk kedepannya. Hal tersebut didukung oleh Skemp (1987:20) mengatakan "jika pemahaman konsep kurang sempurna maka konsep lain yang berkaitan dengan konsep tersebut akan berada dalam masalah yang membahayakan. Akibatnya, akan mengalami hambatan dalam menyelesaikan masalah." Dalam wawancara menunjukkan subjek SC1 tampak ragu, hal tersebut terlihat dari transkip wawancara dimana subjek merasa salah dalam menggunakan sifat logaritma.

Kesalahan lain yang muncul adalah kesalahan pada subjek SC3 dan SC5 yang dalam mengerjakan masalah target sama dengan cara mengerjakan masalah sumber dan dengan hasil akhir yang sama. Subjek SC3 ini terlihat ragu terhadap jawaban yang telah diberikan dikarenakan lupa dengan apa yang menjadi tahap selanjutnya terlihat dari hasil jawaban kedua subjek ini tidak sampai pada pelaksanaan subsitusi yang menjadi pemisalan untuk 
menyelesaikan masalah target. Sehingga jawaban untuk masalah target masih menyisakan variabel lain yang masih sebagai pemisalan. Subjek SC5 ini sudah mampu melakukan tahap penerapan tetapi tidak sampai hasil akhir, dia menganggap bahwa jawaban untuk masalah target sama dengan masalah sumber. Hal ini sesuai dengan apa yang ditemukan dalam penelitian Pang \& Dindyal (2009) bahwa kesalahan dalam penalaran analogi juga terjadi karena pemetaan persepsi yang ada pada masalah sumber yang langsung disesuaikan ke dalam situasi masalah target tanpa analisis pada masalah target terlebih dahulu.

Dalam penelitian ini terdapat hubungan antara ciri-ciri siswa tipe campers dengan penalaran analogi yang telah diteliti. Dengan menggunakan definisi siswa tipe campers yaitu siswa yang dalam proses berpikir masih menunjukkan sejumlah inisiatif, sedikit semangat, tidak menggunakan seluruh kemampuannya, tidak mau mengambil resiko terhadap apa yang akan terjadi dan apabila mengambil resiko dengan penuh perhitungan. Dengan ciri-ciri seperti di atas seharusnya subjek tipe campers akan berhenti pada tahap penerapan penggunaan penyelesaian masalah sumber terhadap masalah target karena sifat nya yang mudah puas, akan tetapi ditemukan dalam penelitian ini bahwa keenam subjek pada penelitian ini masih menunjukkan sedikit inisiatif dalam menyelesaikan masalah target walaupun tidak terlaksana dengan benar, hal ini sesuai dengan sifatnya yaitu subjek sudah memiliki kemauan untuk berusaha menghadapi masalah dan tantangan yang ada, dan berhenti karena merasa sudah tidak mampu lagi.

Dalam peneltian itu pula, penalaran analogi siswa tipe campers mampu melakukan proses terjadinya semua komponen penalaran analogi. Hal ini terlihat dari subjek mampu melakukan tahap pengkodean, penyimpulan, pemetaan dan penerapan. Walaupun pada tahap penerapan, subjek tidak hanya berhenti pada saat menerapkan penyelesaian masalah sumber terhadap masalah target, akan tetapi masih berusaha melakukan langkah selanjutnya pada tahap penerapan, walaupun subjek mengalami kesalahan sehingga tidak mampu menyelesaikan masalah target dengan benar. Adanya pengaruh yang membuat tahap penerapan tidak dapat diselesaikan yaitu kurang teliti dalam menyelesaikan soal dan pemahaman mereka akan konsep logaritma yang salah serta $A Q$ yang dimiliki mengakibatkan subjek tidak maksimal dalam menyelesaikan masalah tersebut. Dan hal tersebut sangatlah berpengaruh terhadap prestasi siswa. Hal ini dikuatkan oleh Wardiana, dkk. (2014), mengemukakan bahwa "Selain $I Q$ dan $E Q$ ada faktor lain yang menunjang prestasi belajar yaitu $A Q^{\prime \prime}$.

\section{Simpulan}

Penalaran analogi siswa tipe campers dimulai dengan melakukan tahap pengkodean pada masalah sumber yakni memahami apa yang telah diketahui dan apa yang ditanyakan dari masalah sumber. Dilanjutkan dengan tahap penyimpulan dimana siswa sudah mampu menghubungkan unsur-unsur yang terdapat pada masalah sumber. Setelah itu subjek melakukan tahap pengkodean pada masalah target. Pada saat melakukan tahap pengkodean siswa mampu memahami apa yang diketahui dan yang ditanyakan pada masalah target serta menyatakan bahwa ada hal yang mirip antara masalah sumber dengan masalah target dan melakukan pemisalan. Setelah tahap pengkodean pada masalah target, siswa melakukan tahap pemetaan dimana siswa mampu melihat hubungan yang sama antara komponenkomponen pada masalah sumber dengan komponen-komponen pada masalah target dan memilih metode penyelesaian yang tepat. Penalaran analogi siswa tipe campers diakhiri dengan tahap penerapan. Pada tahap penerapan subjek mampu mengerjakan masalah target 
dengan menggunakan konsep penyelesaian masalah sumber dengan benar, namun setelah menerapkan konsep penyelesaian masalah sumber terhadap masalah target, terdapat kesalahan dalam menyelesaikan masalah target untuk strategi selanjutnya. Banyak hal yang mempengaruhi hal tersebut, antara lain dikarenakan siswa kurang teliti, pemahaman mereka terhadap konsep logaritma salah dan pengaruh pemetaan persepsi yang ada pada masalah sumber yang langsung disesuaikan ke dalam situasi masalah target tanpa analisis pada masalah target terlebih dahulu.

Hal-hal yang dapat disarankan setelah melakukan penelitian ini adalah perlu ditingkatkan pemberian masalah analogi kepada siswa, sehingga siswa tidak mudah lupa dengan pengetahuan awal, dengan catatan tetap memperhatikan pengetahuan baru yang akan didapat siswa sehingga siswa paham akan konsep pengetahuan baru dalam masalah analogi. Perlu pengembangan model pembelajaran yang dapat membatu siswa meningkatkan penalaran analogi dalam belajar matematika serta perlu juga adanya scaffolding dalam pembelajaran untuk mengatasi permasalahan proses berpikir dengan menggunakan penalaran analogi khususnya pada tahap penerapan terhadap siswa tipe campers. Selanjutnya, perlu dilakukan penelitian serupa dengan subjek ditinjau dari $A Q$, namun berfokus pada tipe selain campers sehingga mampu dijadikan perbandingan.

\section{Daftar Rujukan}

Depdiknas (2006). Peraturan Menteri Pendidikan Nasional Republik Indonesia Nomor 22 Tahun 2006 tentang standar isi untuk satuan pendidikan dasar dan menengah

English, L. D. (2012). Mathematical and analogical reasoning of young learners. New Jersey: Lawrence Erlbaum Associates.

Kariadinata, R. (2012). Menumbuhkan daya nalar (Power Of Reason) siswa melalui pembelajaran analogi matematika. Jurnal Ilmiah Program Studi Matematika STKIP Siliwangi Bandung. Vol 1 no 1.

Khair, M. S. (2018). Penalaran analogi siswa dalam menyelesaikan soal persamaan eksponen dan persamaan logaritma berdasarkan gaya berpikir. Tesis tidak diterbitkan, Malang: Pascasarjana Universitas Negeri Malang.

OECD. 2018. PISA (2015) Results in Focus What 15-year-olds know and what they can do with what they know. OECD.

Pang, W. K. A., \& Dindyal, J. (2009). Analogical reasoning errors in mathematics at junior college level. Makalah disajikan dalam 23 $3^{\text {th }}$ Annual Conference of the mathematics Education Research Group of Australasia Incorporated (MERGA 2009). Wellington.

Shadiq, F. (2004). Penalaran, pemecahan masalah, dan komunikasi matematika. Diklat Instruktur/Pengembangan Matematika SMP Jenjang Dasar. PPPG Matematika : Yogyakarta.

Skemp, R. R. (1987). Psychology of learning mathematics. Expanded american edition. New Jersey : Lawrence Erlbaum Associates Publisher.

Stoltz, P. G. (2000). Adversity Quotient : mengubah hambatan menjadi peluang. Jakarta: GRASINDO.

Sumardyono. (2010). Kemampuan siswa dasar dalam penguasaan istilah dan simbol matematika. Jurnal EDUMAT, Vol 1: (1) : 35-48

Wardiana, I. P. A., Wiarta, I. W.,\& Zulaikha, S. (2014). Hubungan antara adversity quotient (AQ) dan minat belajar dengan prestasi belajar matematika pada siswa kelas V SD di Kelurahan Pedungan. Jurnal Mimbar PGSD. Unversitas Pendidikan Ganesha. Jurusan PGSD Vol 2: (1). 